\title{
Effect of Renewable Energy and Electric Vehicles on Smart Grid
}

\author{
Alaa. A. Zaky \\ Department of electrical Power Engineering \\ University of Kafr elshiekh \\ Kafrelshiekh, Egypt
}

\begin{abstract}
Global electricity demands are increasing at rapid pace. Energy supply, their usage and technologies involved need to be more economical, environment friendly and socially sustainable. Efforts are being done all over the globe to reduce this green house effect; and renewable energy technologies to combat climate changes, which require extensive changes to the current electricity generation and distribution systems. To meet this goal, it is required to optimize the grid operations and available resources to meet the ever increasing energy demands in an efficient, effective and environment sustainable way. So strong and huge interests on smart grid have increased extensively in recent years around the world. This scenario could be a promising reason for future research in this area. This next form of electricity grid will be able to manage various parts of power production from power plants to the customers. Renewable energy sources appear strongly in smart grid so in this paper the effect of this sources will be studied also electric vehicles have a great effect on smart grid infrastructure ,communication and control this paper will discuss this effect if it come from the electric vehicle mode or vehicle to grid mode.
\end{abstract}

Index Terms-- Smart grid, Renewable energy, Distributed Generation, Barriers, Photovoltaic.

\section{INTRODUCTION}

$\mathrm{T}$ HE electrical power generation and distribution using traditional grids that serve consumers to day have been evolved over more than a hundred years. Current grids have served well in the past but will not be adequate in the future $[1,2]$ in terms of their efficiency and environment friendliness. However, new challenges are arising from ever increasing consumer demands, global warming and depletion of nonrenewable energy sources at much rapid rate [3,4]. Electricity grids must ensure safe, secure, uninterrupted and sustainable electricity supplies; take advantage of new technologies and integrate with large scale renewable generation systems. To meet requirement of managing intermittency of renewable energy sources intelligently to avoid future supply failures, which provide an excellent opportunity for the deployment of smart grid technologies adoption needs to be considered as an excellent opportunity [5] the smart grid architecture is shown in figure 1. As peak demand of electricity is increasing at rapid pace in all regions, smart grids deployment may also help in managing the increase in projected peak demand [6].

1. Drivers of smart grid

The electricity supply industry is facing lot of challenges: supply-demand gap; rising costs; low energy efficiencies; and global warming, caused by traditional electricity generation and distribution practices. Also there are many other factors which are driving the need for adoption and implementation of the smart grid technologies. Some of the key drivers of smart grid technologies are: increasing demand of electricity; supply shortfalls of electricity; need of reduction losses; peak demand manage- ment; integration of renewable energy generation systems; solution to global warming; effective use of electric vehicles; better customer satisfaction; overcoming difficulties in meter reading; poor efficiencies of conventional power generation systems; potential of technological advancements and new business opportunities [7]. A summary of these important drivers have been given below.

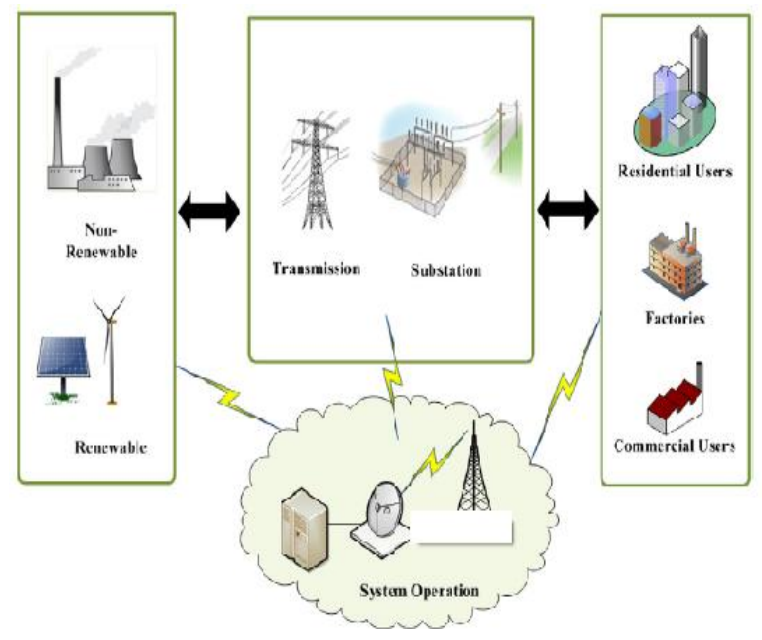

Fig. 1. Smart grid power system architecture.

1.1 Increasing demand of electricity

Global energy demand increased may be assigned to many valid reasons: increasing world population; growing needs of products; rapid industrialization rate; high customized and digitalized services; rapid development of smart home 
appliances; communication systems' electricity demand; lazy lavish life style fostering automation (using electrical and electrical gadgets); increased usage of electricity driven vehicles; late hours working culture requiring appropriate illumination; and increasing demand of electricity in providing human comforts (air conditioning) [8]. As per the International Energy Agency (IEA), the global energy demand will increase by more than 50 percent till 2030 [3]. Due to lack of real-time pricing signals, peak demand is also expected to increase steadily over time [5].

\subsection{Supply shortfalls of electricity}

Supply-demand tension has taken its toll in various countries around the world over the last several years. Governments and utilities have faced gaps between electricity supply and demand, which has led to blackouts and load shedding and translated into electricity shortfalls [9]. Electricity generation is not growing at the same pace as of increase in demand, causing shortfall of electricity supply [10]. 1.3 Need of reduction in losses

Great losses have been observed taking place in generation, transmission, distribution and usage of electricity. These losses need to be appropriately addressed with continuously monitoring to stop the common problems like theft of electricity [11].

\subsection{Peak demand management}

Managing peak demand (which has been observed increasing rapidly over the last few decades because of many valid reasons such increasing number of consumers, affordable electrical appliances and services etc.) may be recognized as challenge of all times. In fact, peak demand mismanagement may lead to: exert extra burden on present electric grid [7]; and require higher reserve margins for unforeseeable outages.

\subsection{Integration of renewable energy generation systems}

Renewable energy technologies can reduce environmental as well as social impacts and provide low cost alternatives than conventional energy technologies for various applications [12]. It will also add to the capacity of existing system and reduce the emission of green house gases, which are responsible for global warming and ozone layer depletion [13]. 1.6 Solution to global warming

It has been accepted globally that environmental pollution has been reached to end limits [11]. It is estimated that the United States is the source of one-fourth of the world's GHG emissions and that the electric power industry accounts for one-third of these [14]. Use of smart grid technologies may be realized as an intelligent and smart answer minimizing GHG.

\subsection{Effective use of electric vehicles}

A smart grid may accommodate electric vehicle charging and it may bring all elements of the electricity system closer together to improve overall system operation for the benefit of consumers and the environment [15]. Smart grid technologies may be utilized to generate environment friendly electricity and feed huge transportation systems like 'Delhi Metro Railway Corporation' network electricity demand.

\subsection{Better customer satisfaction}

Smart grids give consumers a visibility into real-time pricing and provide opportunity to minimize the total amount of their bills by smartly choosing the volume and price of consumption that best suits their needs [16].

\subsection{Overcoming difficulties in meter reading}

Smart metering may enable the meter reading nearly instantaneous and remotely [17] leading to many advantages: less time consuming; cost effective and accurate. Further, it may also lead to have better maintained customer relations by providing transparency in meter reading system.

\subsection{Poor efficiencies of conventional power generation systems}

Traditional power generation systems have been observed with poor efficiencies. Smart grid technologies may be good solution to save a reasonable quantity of fuel and greenhouse gas emissions [5].

\subsection{Potential of technological advancements}

The technological advancement in the field of computing and telecommunications may support the concept of smart grid technologies adoption as it requires lot of measurements monitoring, computing and communications as a network [18]. The development of the smart grid may led to realize the full potential of individual technologies (distributed solar photovoltaic's (PV), electric cars, demand-side management, and large central station renewable such as wind and solar farms) supporting non conventional power generation [5].

\subsection{New business opportunities}

Smart grid technologies implementation may open those to new business opportunities in the field of manufacturing of innovative products, processes and services [7]. Manufacturing of tools, equipments, instruments and apparatus supposed to be used in smart power generation and distribution (like smart power meter); and smart appliances (electric vehicles) may be seen as good examples of business opportunities in manufacturing sector. Taking into account the history of published papers in the area of smart grid Fig. 2 shows the published items about smart grid in a period of 20 years. As shown in Fig. 2, the items about this topic have just been published from 2001. Thus, it is observed that smart grid is extensively new topic. Moreover, before 2008 there were less than 50 papers and only after 2008 this research area has become a hot topic. Obviously, in 2011 there was a rapid increase in number of publications and citations (Fig. 3). Furthermore, although in 2012 the published works were about 1/3 of 2011, however, the citation number, as shown in Fig. 3, is equal in 2011 and 2012. Therefore, the promising future of smart grid will be guaranteed.

\section{PHOTOVOLTAIC MODELS}

With increasing concerns about fossil fuel deficit, skyrocketing oil prices, global warming, and damage to environment and ecosystem, the promising incentives to develop alternative energy resources with high efficiency and Low emissions are of great importance. Among the renewable energy resources, the energy through the photovoltaic (PV) effect can be considered the most essential and prerequisite sustainable resource because of the ubiquity, abundance, and sustainability of solar radiant energy. Regardless of the intermittency of sunlight, solar energy is widely available and completely free of cost. Recently, photovoltaic array system is likely recognized and widely utilized to the forefront in electric power applications. It can generate direct current electricity without environmental impact and contamination 
when is exposed to solar radiation. Being a semiconductor device, the PV system is static, quite, and free of moving parts, and these make it have little operation and maintenance costs. Even though the PV system is posed to its high capital fabrication cost and low conversion efficiency, the skyrocketing oil prices make solar energy naturally viable energy supply with potentially long-term benefits. PV module represents the fundamental power conversion unit of a PV generator system. The output characteristics of PV module depends on the solar insolation, the cell temperature and output voltage of PV module. Since PV module has nonlinear characteristics, it is necessary to model it for the design and simulation of maximum power point tracking (MPPT) for PV system applications. The mathematical PV models used in computer simulation have been built for over the past four decades. Almost all well-developed PV models describe the output characteristics mainly affected by the solar insolation, cell temperature, and load voltage. However, the equivalent circuit models are implemented on simulation platforms of power electronics, such as SPICE. Recently, a number of powerful component-based electronics simulation software package have become popular in the design and development of power electronics applications. The electromagnetic radiation of solar energy can be directly converted electricity through photovoltaic effect. Being exposed to the sunlight, photons with energy greater than the band-gap energy of the semiconductor are absorbed and create some electron-hole pairs proportional to the incident irradiation. Under the influence of the internal electric fields of the $p-n$ junction, these carriers are swept apart and create a photocurrent which is directly proportional to solar insolation. PV system naturally exhibits a nonlinear I-V and P-V characteristics which vary with the radiant intensity and cell temperature.

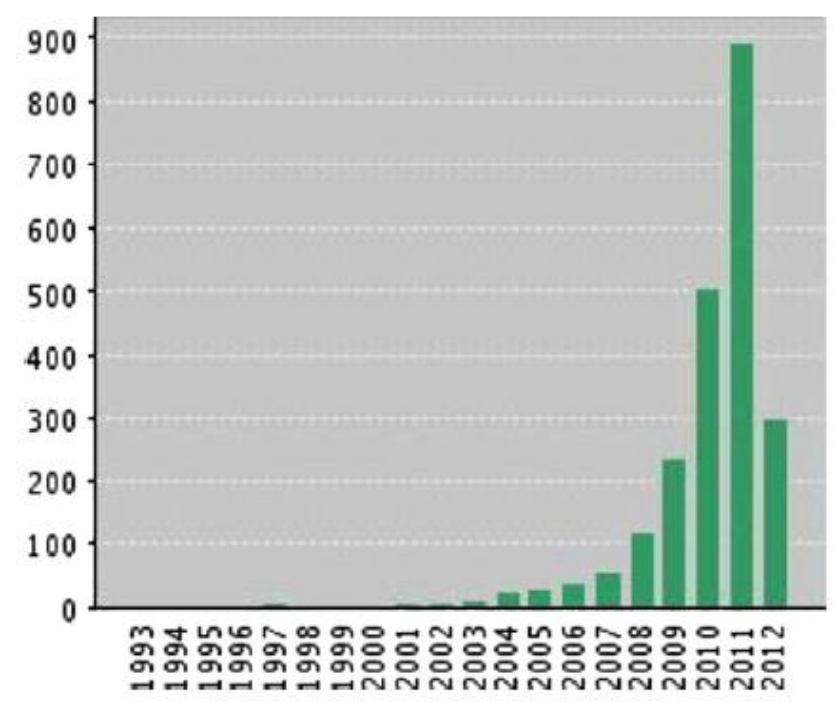

Fig. 2. Published items about smart grid in recent 20 years

The electrical circuit able to represent a photovoltaic module is shown at Fig.4.The proposed simulation model is shown in figs. 5,6and fig.7.From Fig.4

$I_{\text {module }}=I_{\text {ph }}-I_{D}-I_{R P}$
Where: $I_{\text {module }}$ is the photovoltaic module output current; $I_{p h}$ is the Photo-current; $I_{D}$ is the Diode current; $I_{R P}$ is the Parallel resistance current. The voltage-current characteristic equation of a solar cell is given as

$I=I_{\mathrm{PH}}-I_{\mathrm{S}}\left[\exp \left(q\left(V+I R_{\mathrm{S}}\right) / K T_{C} A\right)-1\right]-\left(V+I R_{\mathrm{S}}\right) / R_{\mathrm{P}}$

Where $I_{\mathrm{S}}$ is the cell saturation of dark current, $q(=1.6$ $\times 10-19 \mathrm{C})$ is an electron charge, $k(=1.38 \times 10-23 \mathrm{~J} / \mathrm{K})$ is a Boltzmann'sconstant, $T_{C}$ is the cell's working temperature, $A$ is an ideal factor, $R_{\mathrm{P}}$ is a shunt resistance, and $R_{\mathrm{S}}$ is a series resistance. The photocurrent mainly depends on the solar insolation and cell's working temperature, which is described as

$I_{\mathrm{PH}}=\left[I_{\mathrm{SC}}+K I\left(T \mathrm{C}-T_{\mathrm{Ref}}\right)\right] \mathrm{S}$

Where $I_{\mathrm{SC}}$ is the cell's short-circuit current at a $25^{\circ} \mathrm{C}$ and $1 \mathrm{~kW} / \mathrm{m}^{2}, K I$ is the cell's short-circuit current temperature coefficient, $T_{\mathrm{Ref}}$ is the cell's reference temperature, and $\mathrm{S}$ is the solar insolation in $\mathrm{kW} / \mathrm{m}^{2}$.

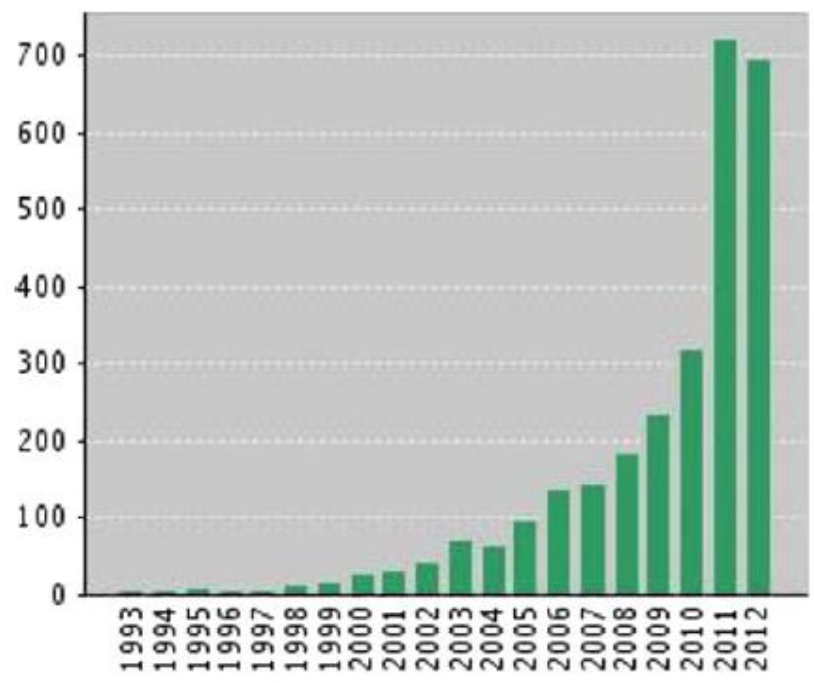

Fig. 3. Citation items about smart grid in recent 20 years.

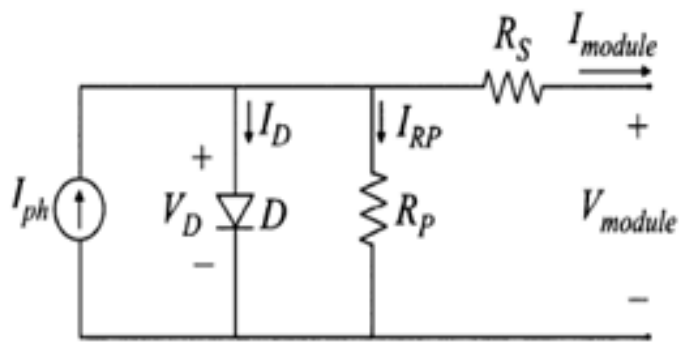

Fig. 4: Photovoltaic module electrical circuit.

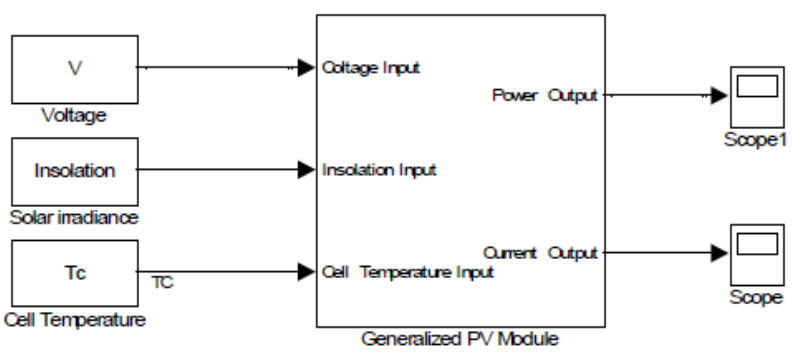

Fig. 5 Generalized PV model. 
Recent Innovations in Mechatronics (RIiM) Vol. 2. (2015). No. 1-2.

DOI: $10.17667 /$ riim.2015.1-2/15.

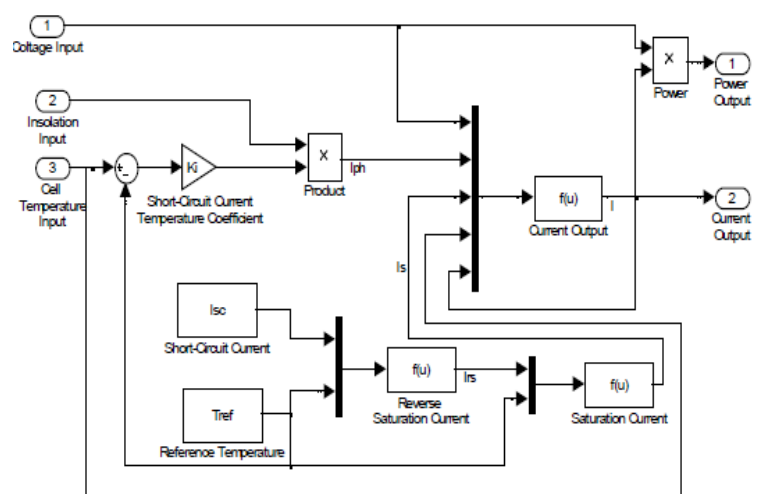

Fig.6 Subsystem implementation of generalized PV model.

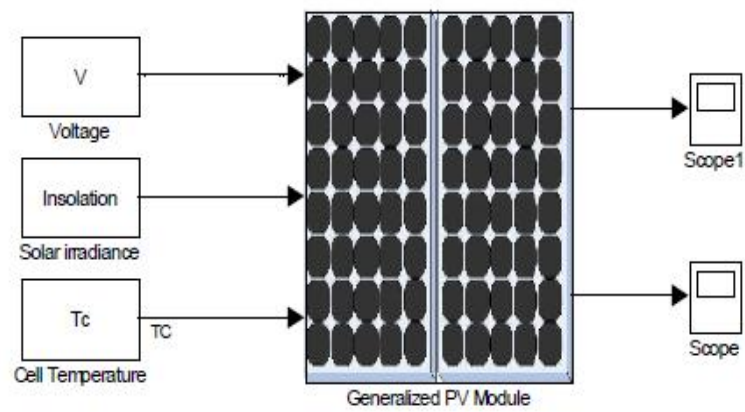

Fig. 7 Masked implementation of generalized PV model.

\section{II.1 Solar cells modules simulation}

The first simulation result is presented to check data-sheet information. In this case, just one module will be simulated, i.e., $N_{s}=N_{p}=1$. Figure shows a comparison between I-V simulations generated curves and data-sheet ones. The photovoltaic module information was extract from Kyocera KC200GT data-sheet. Table I summarizes the main information

TABLE I

KYOCERA KC200GT PHOTOVO LTAIC MODULE SPECIFICAIONS

\begin{tabular}{|c|c|}
\hline \multicolumn{2}{|c|}{ Specifications @ $S=1000 \mathrm{~W} / \mathrm{m}^{2}, \mathrm{~T}=25^{\circ} \mathrm{C}$ and $\mathrm{AM}=1,5$} \\
\hline Maximum Power $\left(P_{\max }\right)$ & $200 \mathrm{~W}$ \\
\hline Maximum Power Voltage $\left(V_{m p p}\right)$ & $26.3 \mathrm{~V}$ \\
\hline Maximum Power Current $\left(I_{m p p}\right)$ & $7.61 \mathrm{~A}$ \\
\hline Open Circuit Voltage ( $\mathrm{V}_{\mathrm{oc}}$ ) & $32.9 \mathrm{~V}$ \\
\hline Short Circuit Current $\left(I_{s c}\right)$ & $8.21 \mathrm{~A}$ \\
\hline $\begin{array}{l}\text { Temperature Coefficient of } I_{s c}\left(U_{I}\right. \\
\text { ) }\end{array}$ & 3. $18 \cdot 10^{\prime \prime} \mathrm{AlC}$ \\
\hline \multicolumn{2}{|c|}{ Specifications @ S $=800 \mathrm{~W} / \mathrm{m}^{2}, \mathrm{~T}=47^{\circ} \mathrm{C}$ and $\mathrm{AM}=1,5$} \\
\hline Maximum Power $\left(P_{\max }\right)$ & $142.2 \mathrm{~W}$ \\
\hline Maximum Power Voltage ( $\left.V_{m p p}\right)$ & $23.2 \mathrm{~V}$ \\
\hline Maximum Power Current $\left(I_{m p p}\right)$ & 6.I3A \\
\hline
\end{tabular}

Analyzing Figure.8, it is possible to notice that both, datasheet and simulation results, are in total accordance. The proposed modeling is able to represent the photovoltaic issue to a wide range of radiation and temperature variation. In order to check the precision of the modeling, simulation results, specific environment condition, are presented in Fig. 9. The present results confirm and validate the modeling. The measured points at the graphic, practically, coincide to the Table I data.

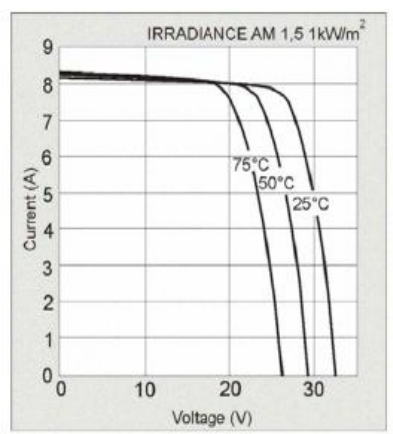

(a)

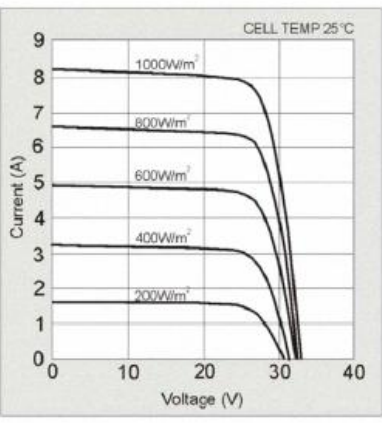

(c)

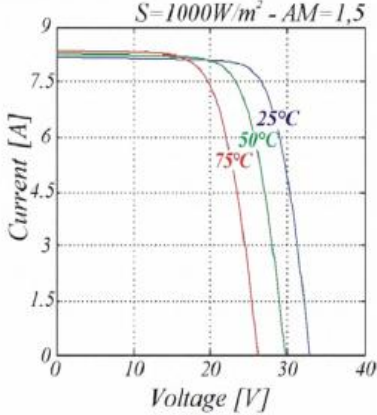

(b)

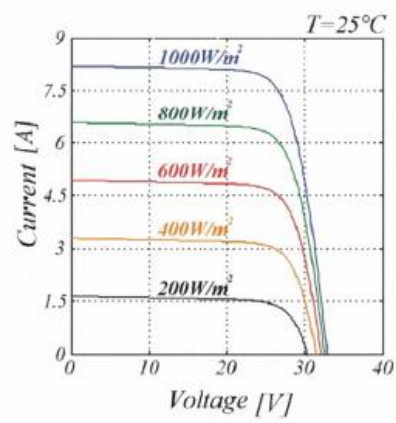

(d)
Fig.8 Data-sheet and simulation I-V curves to the photovoltaic module. (a) and (c): data-sheet;(b) and (d): simulation

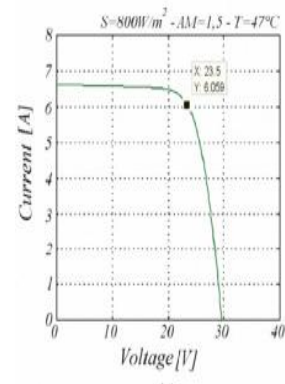

(c)

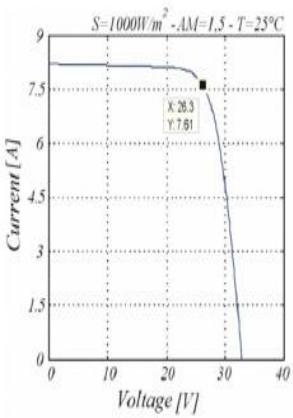

(a)

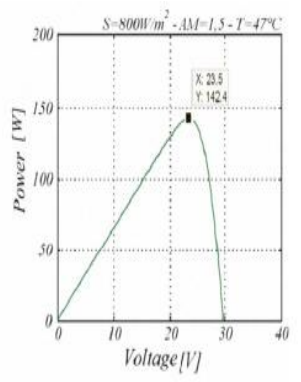

(d)

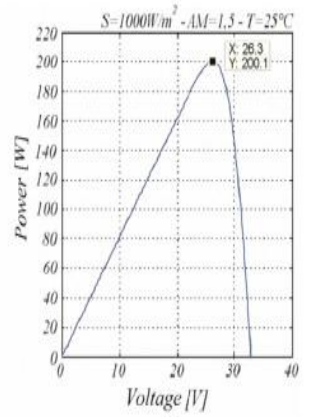

(b)
Fig.9 Simulation result s. (a) and (b) : $\mathrm{S}=1000 \mathrm{~W} / \mathrm{m}^{2}, \mathrm{~T}=25^{\circ} \mathrm{C}$; (c) and (d): 
$800 \mathrm{~W} / \mathrm{m}^{2}, \mathrm{~T}=47^{\circ} \mathrm{C}$.

Next simulation will consider a photovoltaic association, constituted by 54 modules. The array configuration is shown at Table 2 .

TABLE 2

KYOCERA KC200GT PHOTOVOLTAIC ARRAY SPECIFICATIONS

\begin{tabular}{|l|l|}
\hline Specifications @ $\mathrm{S}=1000 \mathrm{~W} / \mathrm{m}^{2}, \mathrm{~T}=25^{\circ} \mathrm{C}$ and $\mathrm{AM}=1,5$ \\
\hline$N_{p}$ & 3 \\
\hline$N_{s}$ & 18 \\
\hline Maximum Power $\left(P_{\max }\right)$ & $10.8 \mathrm{~kW}$ \\
\hline Maximum Power Volt age $\left(V_{m p p}\right)$ & $473.4 \mathrm{~V}$ \\
\hline Maximum Power Current $\left(I_{m p p}\right)$ & $22.83 \mathrm{~A}$ \\
\hline Open Circuit Voltage $\left(\mathrm{V}_{\mathrm{oc}}\right)$ & $592.2 \mathrm{~V}$ \\
\hline Short Circuit Current $\left(I_{s c}\right)$ & $24.63 \mathrm{~A}$ \\
\hline
\end{tabular}

From the mathematical modeling and array specifications some simulations were realized. The main results are presented in Figure 10.

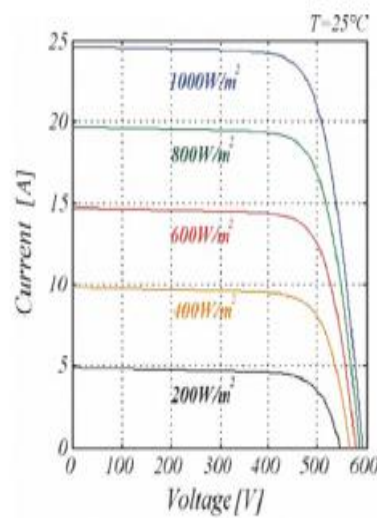

(a)

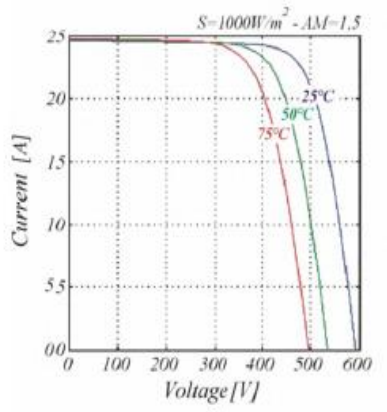

(c)

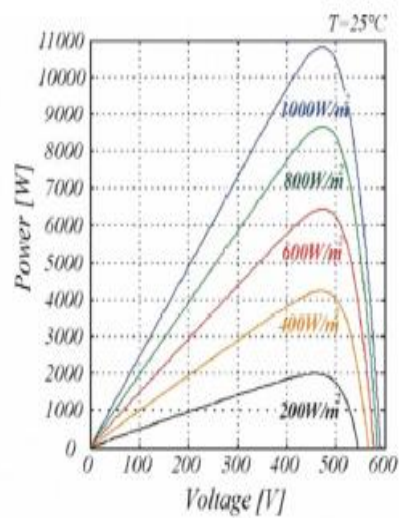

(b)

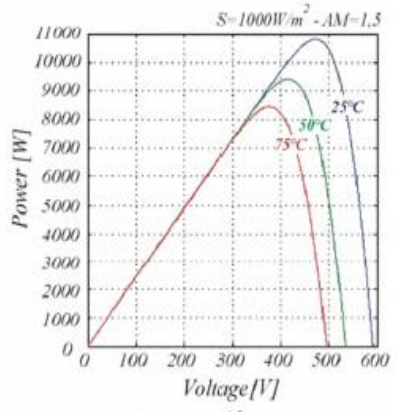

(d)
Fig.10 Data-sheet and simulation I-V curves to the photovoltaic array under different value of radiation and temperature

For a PV cell with an ideal I-V characteristic, its open circuit voltage and short-circuit current are given as $V_{\mathrm{oc}}=0.596 \mathrm{~V}$ and $I_{\mathrm{sc}}=2.0 \mathrm{~A}$, respectively. In addition, $N_{\mathrm{S}}=N_{\mathrm{P}}=1$ for a PV cell. Both I-V and P-V output characteristics of generalized PV model for a cell are shown in Figs. 11-12. The nonlinear nature of PV cell is apparent as shown in the figures, i.e., the output current and power of PV cell depend on the cell's terminal operating voltage and temperature, and solar insolation as well. We find from Figs. 11(a) and 11(b) that with increase of working temperature, the short-circuit current of the PV cell increases, whereas the maximum power output decreases. Inasmuch as the increase in the output current is much less than the decrease in the voltage, the net power decreases at high temperatures. On the other hand, we observe from Figs. 12(a) and 12(b) that with increase of solar insolation, the short-circuit current of the PV module increases, and the maximum power output increases as well. The reason is the open-circuit voltage is logarithmically dependent on the solar irradiance, yet the short-circuit current is directly proportional to the radiant intensity. By the same token, the Solarex MSX 60 PV module is taken for example. The key specifications are listed in Table 3 in which the nominal operating cell temperature (NOCT) is the temperature that the cells will reach when they are operated at open circuit in an ambient temperature of $20^{\circ} \mathrm{C}$ under $\mathrm{AM} 1.5$ irradiance conditions with $S=0.8 \mathrm{~kW} / \mathrm{m}^{2}$ and a wind speed less than $1 \mathrm{~m} / \mathrm{s}$. The electrical characteristics of PV module are generally represented by the current versus voltage and power versus voltage curves. Both I-V and P-V output characteristics of PV module at various insolation and temperatures are carried out and the results are shown in Figs. 13-14. We also see from Figs. 13(a) and 13(b) that with increase of working temperature, the short-circuit current of the PV module increases, whereas the maximum power output decreases. The increase in the short-circuit current is much less than the decrease in the open-circuit voltage, and the effect makes maximum power decreasing by about $0.45 \% /{ }^{\circ} \mathrm{C}$ at high temperatures. On the other hand, from, we also observe that with increase of solar insolation, the short-circuit current and the maximum power output of the PV module increase as shown in Figs. 14(a) and 14(b). The reason is the open-circuit voltage is logarithmically dependent on the solar irradiance, yet the short-circuit current is directly proportional to the radiant intensity. For easy simulation, the solar radiation intensity for a sample day is assumed to be a function of Gaussian function which is defined as

$$
\mathrm{S}(\mathrm{t})=\mathrm{S}_{\max } \exp \left[-\left(\mathrm{t}-\mathrm{t}_{\mathrm{C}}\right)^{2} / 2 \sigma^{2}\right]
$$

where $S_{\max }$ is the maximal radiation intensity at a given time, $\mathrm{t}_{\mathrm{C}}$ is the center time, and $\sigma$ is the standard deviation of Gaussian function. Fig. 9 shows a plot of the Gaussian function for the solar radiation intensity for a sample day with the conditions $\mathrm{S}_{\max }=1 \mathrm{~kW} / \mathrm{m}^{2}, \mathrm{t}_{\mathrm{C}}=12$, and $\sigma=0.5$. The peak of sunlight intensity occurs at noon. The cell temperature for a sample day is assumed to be at a fixed temperature of nominal operating cell temperature (NOCT) by ignoring the effect of the solar irradiation. Given sunlight irradiance for a sample day, the output current is governed by its output voltage which is determined by the ensuing load. Without taking cell temperature variations into consideration, the maximum power is determined by both radiation intensity and output voltage. For different output voltage, the output power is shown in Fig. 16 for a sample day. For easy comparisons, the root mean square (R.M.S.) values of output power for various output voltage for a sample day are calculated an depicted in Fig. 17. The maximum R.M.S. power during the course of a sample day occurs with the output voltage in the range of $15-16 \mathrm{~V}$. 
Recent Innovations in Mechatronics (RIiM) Vol. 2. (2015). No. 1-2.

DOI: $10.17667 /$ riim.2015.1-2/15.

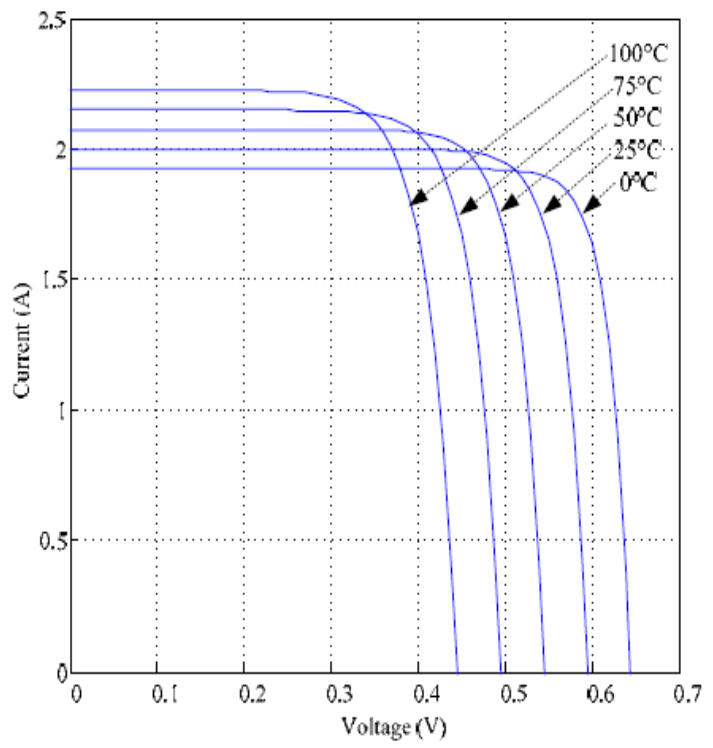

Fig.11(a) I-V output characteristics with different $T c$

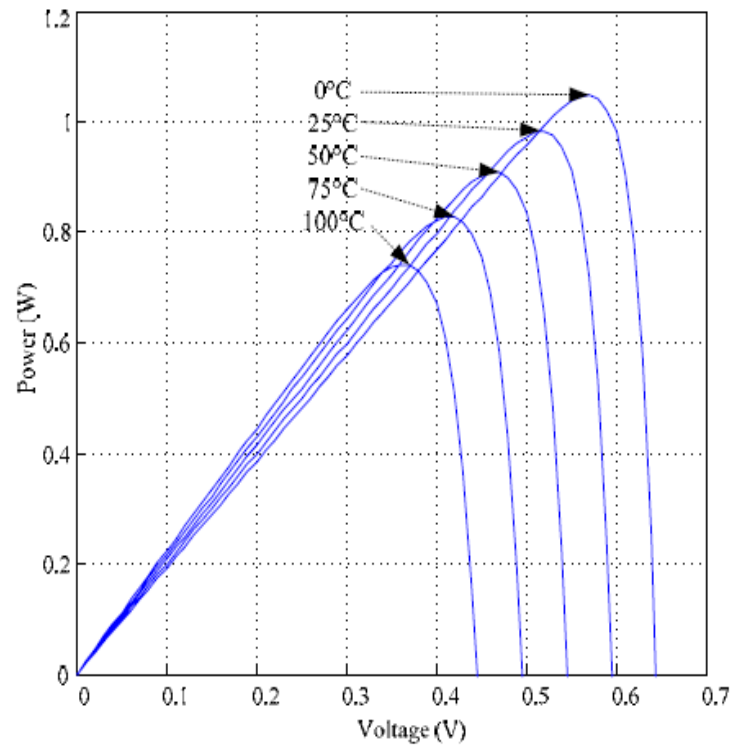

Fig.11(b) P-V output characteristics with different $T c$

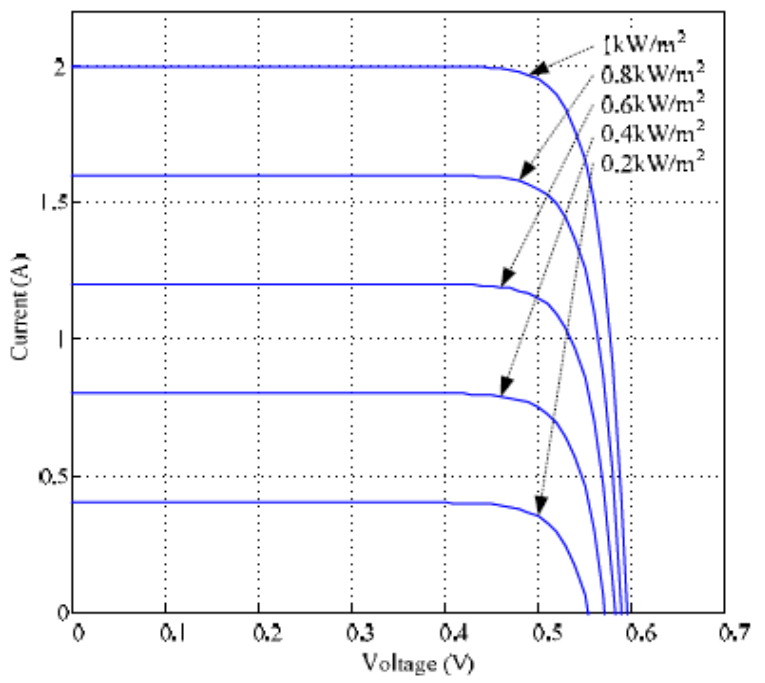

Fig.12(a) I-V output characteristics with different S

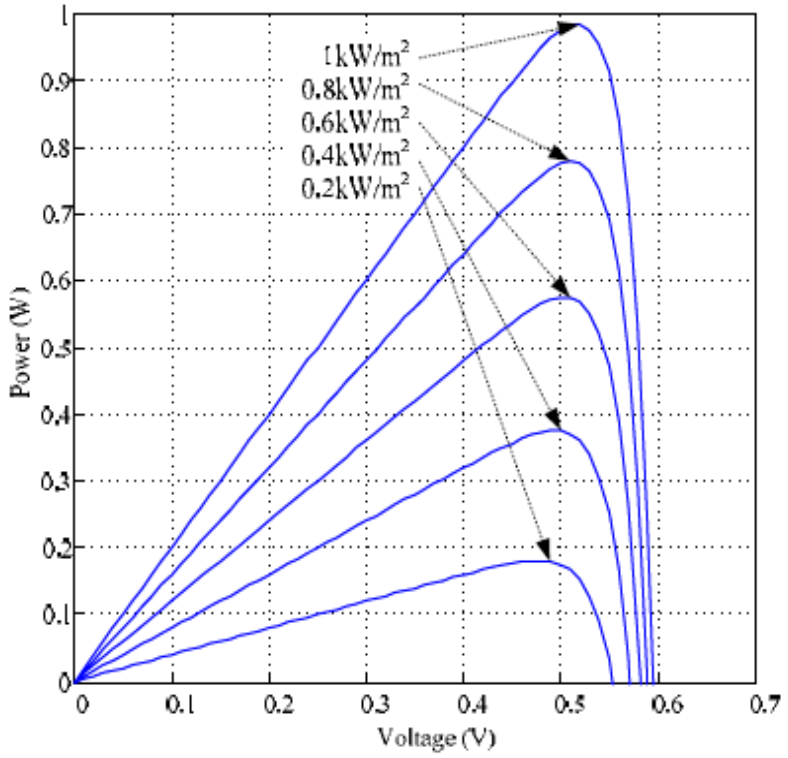

Fig.12(b) P-V output characteristics with different $S$.

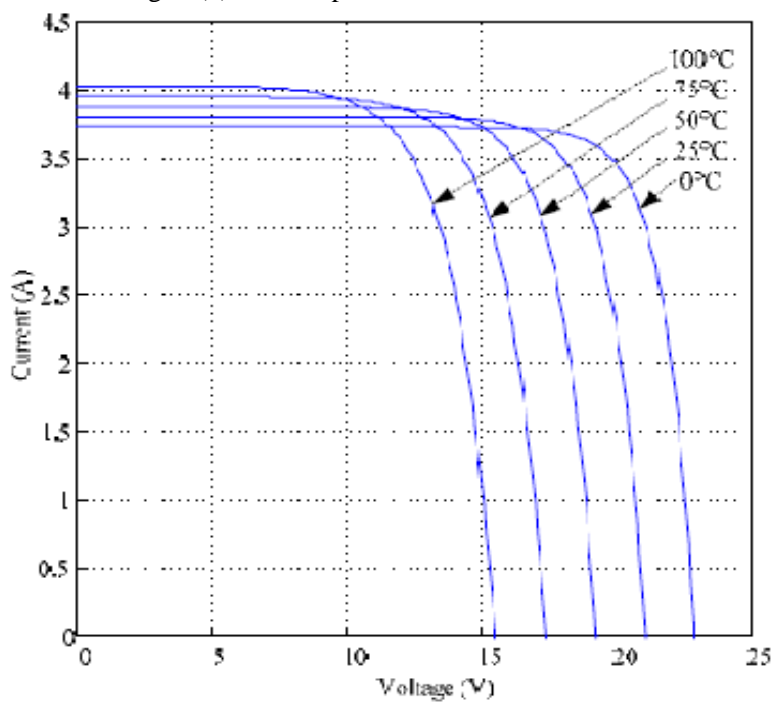

Fig.13(a) I-V output characteristics with different $T c$

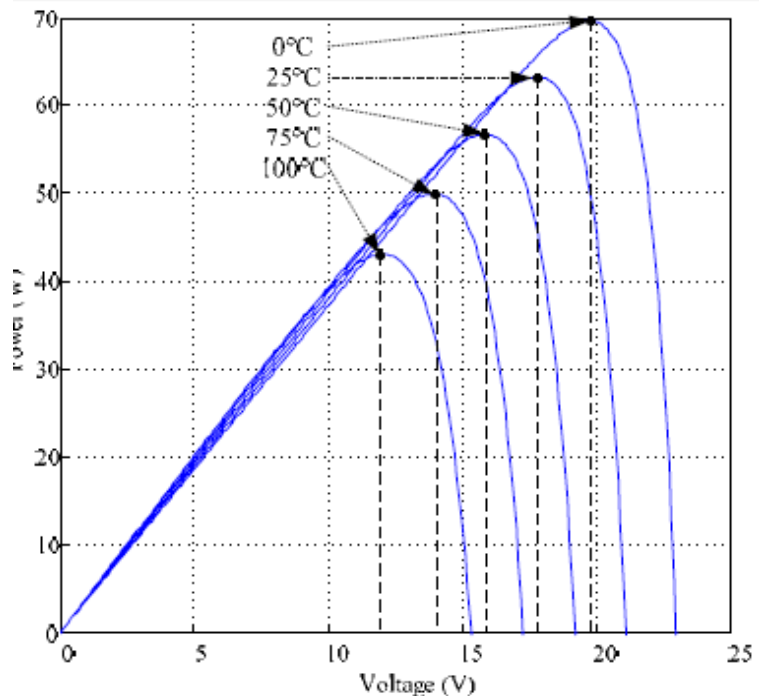


Recent Innovations in Mechatronics (RIiM) Vol. 2. (2015). No. 1-2.

DOI: $10.17667 /$ riim.2015.1-2/15.

Fig.13 (b) P-V output characteristics with different $T c$

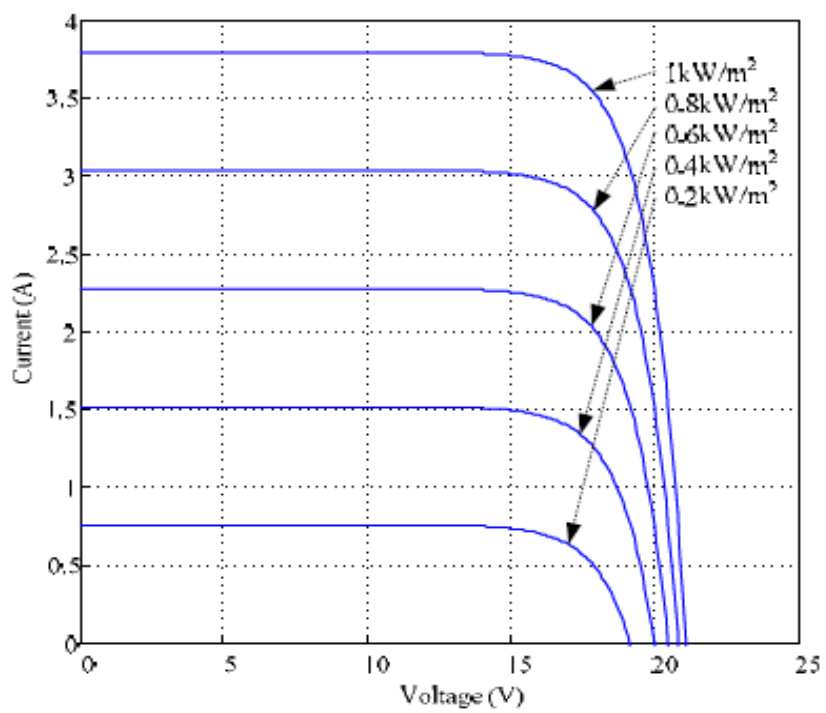

Fig.14(a) I-V output characteristics with different S.

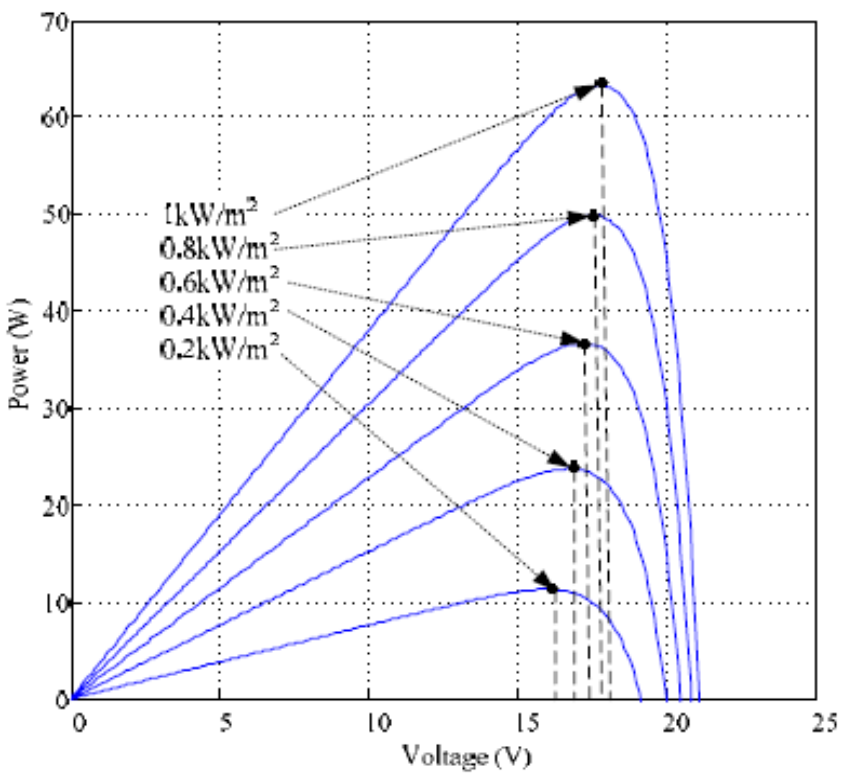

Fig.14(b) P-V output characteristics with different S.

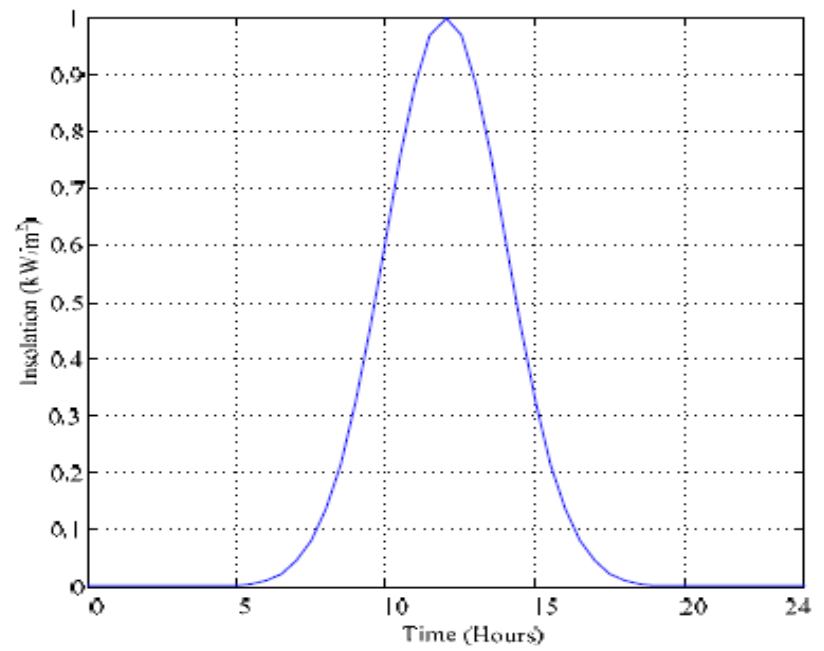

Fig.15 Solar radiation intensity for a sample day in the form of Gaussian function

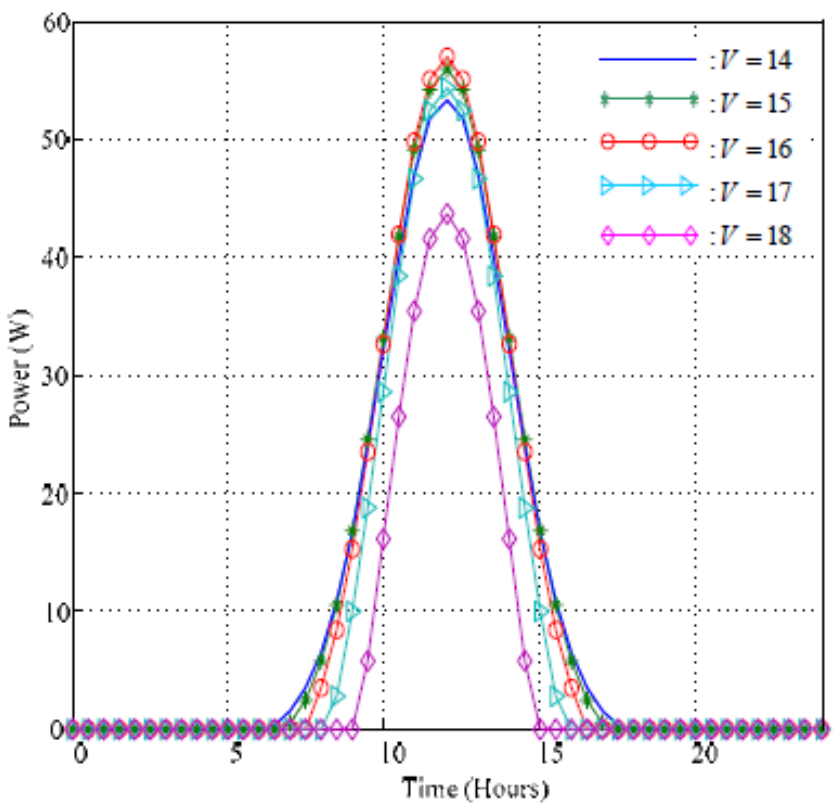

Fig.16 Power characteristics during a sample day for different voltage.

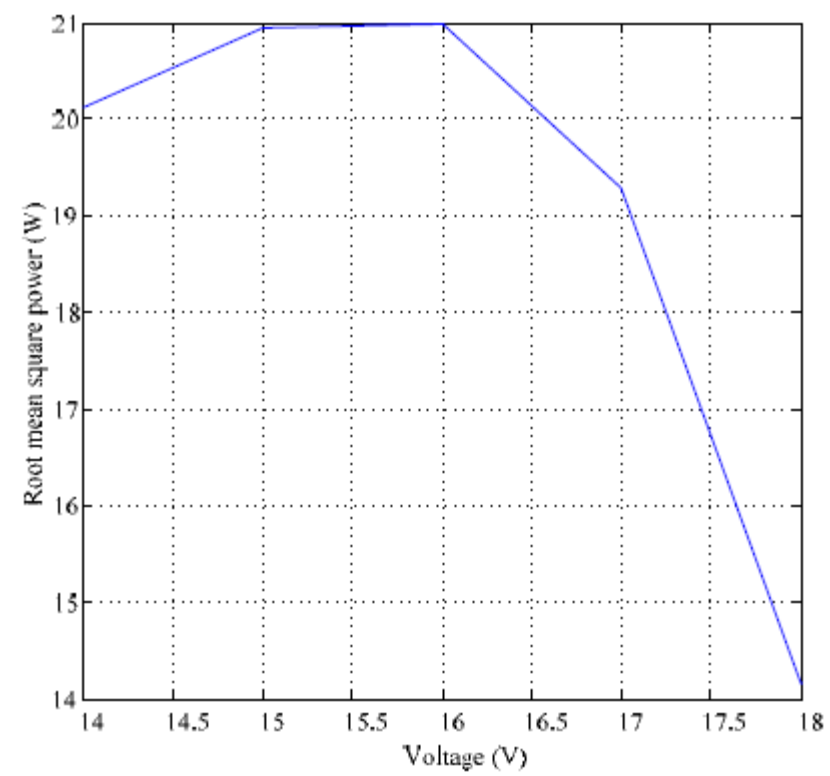

Fig.17 R.M.S. values of output power for various output voltage

TABLE 3

SOLAREX MSX 60 SPECIFICATIONS $\left(1 \mathrm{KW} / \mathrm{M}^{2}, 25^{\circ} \mathrm{C}\right)$

\begin{tabular}{|c|c|}
\hline Typical Maximum Power $\left(P_{\max }\right)$ & $60 \mathrm{~W}$ \\
\hline Maximum Power Voltage $\left(V_{m p p}\right)$ & $17.1 \mathrm{~V}$ \\
\hline Maximum Power Current $\left(I_{m p p}\right)$ & $3.5 \mathrm{~A}$ \\
\hline Short-circuit current $\left(I_{\mathrm{SC}}\right)$ & $3.8 \mathrm{~A}$ \\
\hline Open-circuit voltage $\left(V_{\mathrm{OC}}\right)$ & $21.1 \mathrm{~V}$ \\
\hline $\begin{array}{c}\text { Temperature coefficient of open- } \\
\text { circuit voltage }\end{array}$ & $73 \mathrm{mV} / \mathrm{C}$ \\
\hline $\begin{array}{c}\text { Temperature coefficient of short- } \\
\text { circuit current }\left(K_{I}\right)\end{array}$ & $3 \mathrm{~mA} / \mathrm{C}$ \\
\hline $\begin{array}{c}\text { Approximate effect of } \\
\text { temperature on power }\end{array}$ & $0.38 \mathrm{~W} / \mathrm{C}$ \\
\hline $\begin{array}{c}\text { Nominal operating cell } \\
\text { temperature (NOCT) }\end{array}$ & $49 \mathrm{C}$ \\
\hline
\end{tabular}


2. Barriers to smart grid Technologies adoption identification Today's grids are based on thermal power generation systems observed with less efficiency and emission of GHG gases, which in turn causes global warming and ozone layer depletion. These are connected to large central power stations high voltage transmission systems and supply power to medium; and low-voltage local distribution systems [1]. These conventional grids have been reported lacking in advance monitoring and controlling features. Conventional sources of energy are also depleting at very rapid pace and they are expected to vanish within few decades. In this scenario, smart grid technologies adoption becomes more important and relevant. The benefits of the smart grid are substantial; and it has the potential to reduce GHG emissions, reduce energy costs, fulfill growing needs and improve load control [2]. However, the potential advantages of smart grid technologies are very attractive, the extent of smart grid technologies adoption and actual realization of benefits is very low. Only a small portion of the companies have begun experimenting for advancement and making it practically feasible to adopt [23]. Various barriers to implement smart grid technologies adoption have been identified from the literature review; sorted after discussions with experts; and validated by experts' opinions and brain storming session. Literature was reviewed to identify potential barriers to smart grid technologies adoption followed by conduction of an idea engineering workshop with experts (academia and industry) to validate the identified barriers from literature review. Four experts were from academia and three experts were from industry. Brain storming session was conducted to reach consensuses about the contextual relationships (pair wise) to form a structural self interaction matrix Twelve most important relevant barriers in adaptation of smart gird technologies, resulted from above mentioned exhaustive exercise, have been briefly detailed.

2.1. Huge amount of investment and lack of financial resources

Implementation of smart grids will require additional investment and financial reserves for the smart grid technology transfer, provision of adequate infrastructure, communication systems, hiring of skilled professionals (engineering and other professionals), R\&D work and integration with renewable energy sources. However, the payback period is relatively long comparing against high initial investment [24]. Although, substantial environmental and societal benefits may be achieved by implementation of smart grid technologies, government authorities may need to have sufficient proofs for justification for high investment [19]. Vendors' and original equipment manufacturers' reluctance has to be properly removed by ensuring guaranteed return (long term) to systematic payback scheme supported by incentives and subsidies provided by government authorities [25]. Also, many developed and developing nations affected by the global recession are struggling to pay for renewal of the entire major infrastructure and are facing financial challenges [26].

\subsection{Market uncertainty}

There are not yet specific policies and regulations for free markets tariffs [27]. The standards and business modes of smart grids have to be established towards universally accepted standardized regulatory definitions to generate revenue [29-31]. Adequate in International bodies 'consensus and government consensus, strong political commitment and global cooperation are lacking to organize the dynamics of energy market [1].

\subsection{Lack of regulatory frame work}

Most of the electrical systems of world regulate electric power through policies and regulatory frame works designed along back ago [32]: although appropriate for those times, many of those regulations are now obsolete. Traditional regulatory systems are not harmonized and tend to discourage investment in innovative technologies like smart grid. The regulatory aspects of the smart grids are currently ambiguous [33-36]. Power utility related policies and procedures may be framed to assure compliance with legislative or regulatory requirements for smart grid technologies implementation [37]. 2.4. Low public awareness and engagement

Customer requirements for the smart grid technologies are lacking due to inadequate incentives for consumers to adopt systems to manage their electricity consumption [38]. General public need to be educated and aware through properly managed awareness programs educating them about benefits of smart grid and technicalities of usage smart grid may be installed with advanced metering and two-way communication along with time-of-use rates. Reluctance of public for adoption of smart grid installations is to be carefully tackled. Consumer advocates may object to certain smart grid functionality, such as remote disconnect and new rates in the interest of protecting disadvantaged consumers [25].

\subsection{Lack of innovativeness in the industry}

Organizational attitudes towards innovation may be very discouraging [23]. Instead of looking for innovative solutions to the problems of societal benefits, they want to work with traditional methods for safe and guaranteed return on investment. From a company's point of view, implementing a smart energy solution in a previously well-functioning environment may reduce reliability and evokes worries about a loss of control, if automatic switching operations are intended. Companies have fear of losing their traditional customers if they start using innovative technologies [29]. Innovation in technologies and systems like smart meters, energy controllers, communication systems have been required for improving efficiencies in the smart grids [39].

\subsection{Lack of infrastructure}

Additional infra structure will be required for the deployment and operation of smart grid technologies. The smart grid maybe understood as modern electric power grid infrastructure for improving efficiency and reliability through automated control, high power converters, modern communications infrastructure, sensing and metering technologies, and modern energy management techniques based on the optimization of demand, energy and network availability, and soon [17]. A well defined communication architecture, sensors, intelligent electronic devices, distributed energy resources, cyber security devices, advanced metering system and other end-use devices are key elements of smart grid which need to be added in the present electricity system [33]. Additional stand-by capacity of electricity generation 
might be required for the times when the intermittent renewable energy resources cease to generate power [1].

\subsection{Technology immaturity}

As the smart grid technology is still emerging and standards are not in place, all of its features are not yet tested and proved [32] and technology need to validate estimates of customer load with customer data [31]. The processes of smart grid deployment maybe slow due to technology immaturity; and non confirmation about small scale capital investments and returns on it [23]. Further, because of this immaturity of technology, ancillary facility cannot cop up with the requirements of smart grids [30].

\subsection{Lack of necessary technical skills and knowledge}

As we move towards achieving technology transfer process completion and further utilizing the technology, there would be continuous demand for new cadre of trained engineers and managers to bridge the gap and to develop new skills in analytics, data management and decision support [32]. The utility industries find technical competence as one barrier to the adoption of smart grid technologies and organizations may postpone or even cancel the adoption decision because of the lack of necessary technical skills and knowledge [23].

2.9. Integration of the grid with large scale renewable generation

To enhance the capacity of electricity systems and reduce their dependency on non-renewable energy sources, Integration of both central and distributed generation may be identified important; and integration of the grid with large scale renewable generation requires coordination among different suppliers of energy [7]. It may also require efficiently linking the different power sources with the growing demands of consumer [1]. An important feature of smart grids is the interconnection between large number of dissimilar energy distribution networks, power generating sources and energy consumers [21] leading to many benefits: economic; environmental; social; operational etc. Proposed smart grid may be an ultra large scale system of systems where different systems need to exchange meaningful, actionable information, with common meaning and agreed types of responses to a degree which has not been used in the industry before [35]. Lack of coordination between electric energy and telecom agencies is a barrier to effective smart grid development [27]. 2.10. Need of advanced bi-directional communication systems

Bi-directional flow of energy and information may be recognized as backbone of smart grid; and advanced communications technology is an essential enabling component of the future smart grid. The smart metering communications is a major component of the overall smart grid communications architecture [21]. Distribution of real time control of electricity networks among different generating points, transmission networks and end-users may be a challenging job [40]. Control systems will have to be modified and new operating procedures will need to be developed like dealing not only with the bidirectional power as well as twoway data communication system [41].

2.11. Lack of open standards

Lack of clear standards and guidelines across the grid to support system interoperability, has been identified as a barrier to smart grid deployment [29]. Interoperability standards set for energy distribution networks, power generating sources and energy consumers, may not keep pace with smart grid installations. Many proprietary standards which are in use today are required to be replaced by open standards and open standards will help in encouraging multiple suppliers to innovate new technologies and compete with regards to features and performance [35]. The smart grid installation may become very successful following the success story of internet adopting consistent and open standards worldwide like HTML and internet protocol. In fact, open standards for smart grid installation have been observed in either introduction phase or development phase in various developing and even in developed countries. It is going to take long time in completing, stabilizing and normalizing them [42].

2.12. Cyber security and data privacy

Smart grid communications may play an important role in maintaining high levels of electric systems': reliability; performance and manageability. But at the same time, the grid may to subjected to attack because many of the technologies being deployed to support smart grid projects, like smart meters, sensors, and advanced communication networks, are interoperable and open [7,24]. Frequent smart metering data collection and analysis may help in improving energy efficiency and framing future policy, however this comes at the cost of user privacy [21]. Cyber systems may be vulnerable to worms, viruses, denial-of- service attacks, malware, phishing, and user errors that compromise integrity and availability [43]. Analyzing and implementing smart grid security may be a challenging task, considering the scale of the potential damages that could be caused by cyber attacks [44].

2.13 Effect of solar cells and electric vehicles on smart grid

Solar cells energy is widely used in now a days and it is the future of energy with wind energy and other renewable energy resources. Electric energy can be produced from solar energy in two ways one is direct and it is the solar cells the other is indirect and this way use solar energy as a source of heat and then use the heat energy to produce the steam that drive the steam turbine which act as a prime mover for synchronous generator. The solar energy affect on smart grid as a type of distributed generation (DG) it's effect is in the way of connection is it directly to grid in other words is used as a supply or it is connected to the consumer load directly (isolated mode) or it is connected to the consumer load and in peak of solar cells output it give the over energy to the grid. In the way of a connection as a supply and at the consumer load and in peak of solar cells output it give the over energy to the grid the data way is affected because of different radiation of sun and temperature of solar cells and their effect on solar cells output (I-V and P-V) as discussed previously. Electric vehicles is the future of cars and it has two modes the first is Electric vehicles(EV) charging from the grid as shown in fig.18 and fig.19 the other mode is vehicle to grid (V2G) in this mode the car is connected to grid as a backup source of electric energy. Electric vehicles is charging when the energy in the grid comes from solar or wind to less the emission gases of conventional stations this require a good data and a 
communication link to a chive this from this point of view the effect of solar energy on smart grid is obvious in combining with EVs the effect of solar energy on smart grid is great because of charging EVs only when energy comes from solar energy require a good data link to enable the control center to manage this action.

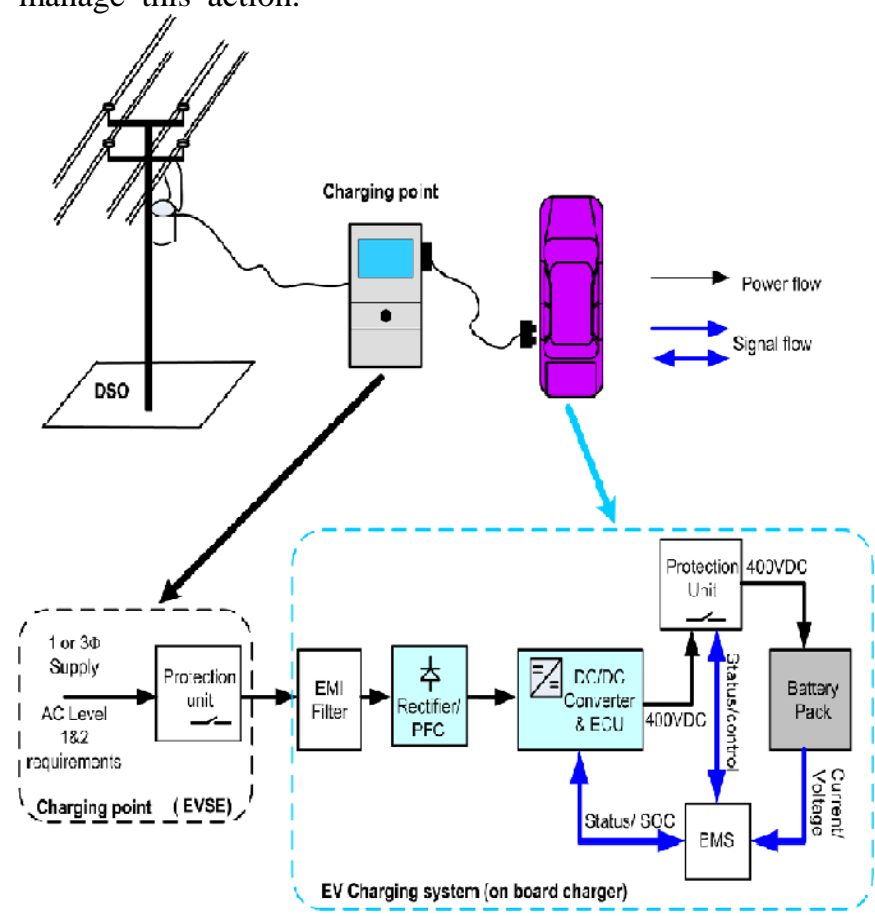

Fig. 18. EV charging configuration at $\bar{A} \bar{C}$ level $1, \overline{2}$ (i.e. onboard

charger).

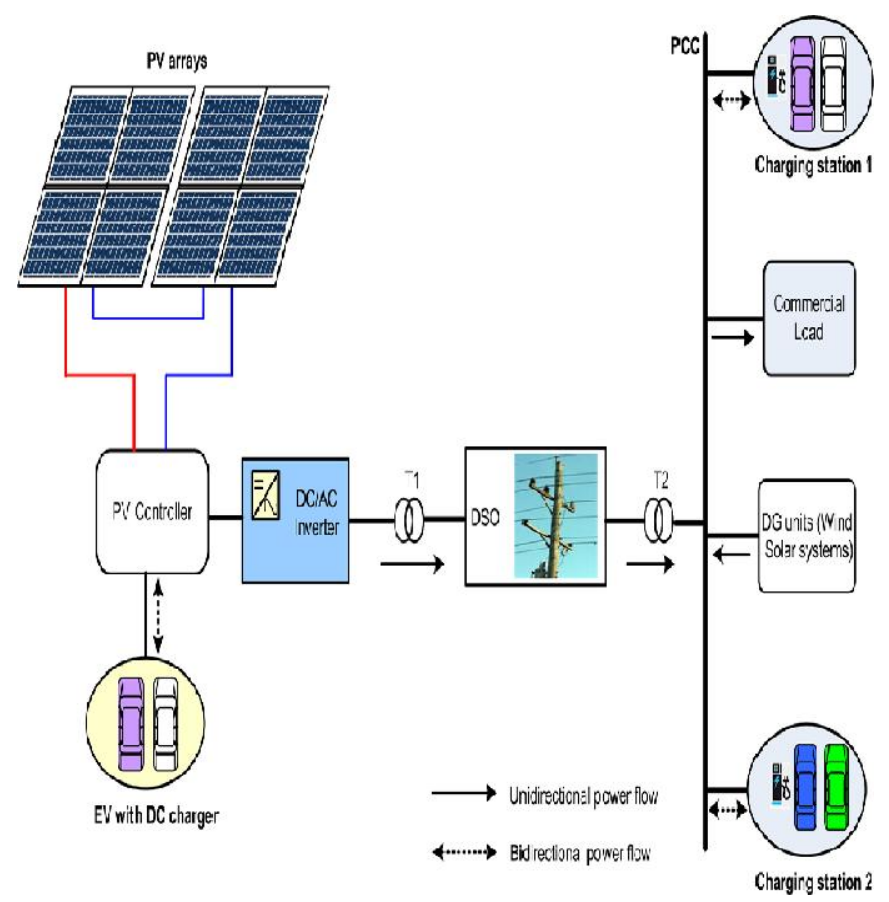

Fig. 19. EV charging station based on grid connected PV solar at the parking lot.

\section{CONCOLUSION}

A generalized PV model which is representative of the all PV cell, module, and array has been developed with Matlab/Simulink and been verified with a PV cell and a commercial module. The proposed model takes sunlight irradiance and cell temperature as input parameters and outputs the I-V and P-V characteristics under various conditions. The smart grid configuration, drivers and obstacles have been discussed .The effect of solar cells on smart grid as a type of distributed generation also discussed and it is obvious that solar cells energy is very important thing in smart grid as it affect on the smart grid configuration and the flow of data because of electric vehicles (EV) charging mode or vehicle to grid mode (V2G).

\section{REFERENCES}

[1] EUR22040-European technology plat form smart grids: vision and strategy for Europe's electricity networks of the future. Publication of European Commission, isbn: 92-79-01414-5; 2006.

[2] Hamilton BA. Understanding the benefits of the smart grid: smart grid implementation strategy. Report for the United States Department of Energy's National Energy Technology Laboratory; 2010.

[3] Birol F. World energy prospects and challenges. AustEconRev2006; 39(2):190-5.

[4] Armaroli N, Balzani V. The future of energy supply: challenges and opportunities. AngewChemIntEd2007;46(1-2):52-66.

[5] Brown MA, Zhou S. Smart-grid policies: an international review. Wiley Interdiscip Rev: Energy Environ2013; 2(2):121-39.

[6] Technology Roadmap: Smart Grids. Report by International Energy Agency (IEA); April2011.

[7] The smart grid vision for India's power sector: a white Paper. Prepared by PA Government Services 2010; Online available at: 〈http://www.sari-energy.org / Page Files/What_We_ Do/ activities / smart_grid_vision _ for _ India _ power_ sector_June _ 2010/ White_ paper Th _ \%20 Smart_Grid_Vision_for_India/White_ Paper_on _the _Smart_Grid _Vision_for_India _-_final. Pdf $>$ [accessed 11.3.12].

[8] Kaygusuz K. Energy services and energy poverty for sustainable rural development. Renew Sustain Energy Rev 2011; 15(2):936-47.

[9] SHORT FALL, E. Managing an electric shortfall - a guide for policy makers. Central America Regional Programmatic Study for the Energy Sector; November, 2010.

[10] ] Bureau of Research on Industry \& Economic Fundamentals, India. Online available at: 〈http://www.ficci.com/Sedocument/20218/PowerReport2013. pdf $\rangle$ [accessed 23.09.12].

[11] Ibrahim O, Fardoun F, Younes R, Louahlia- Gualous H. Energy status in Lebanon and electricity generation reform plan based on cost and pollution optimization. RenewSustainEnergyRev2013; 20:255-78.

[12] Martinot E, Reiche K. Regulatory approaches to rural electrification and renewable energy: case studies from six developing countries. Washington, DC: World Bank; 2000.

[13] PrattR, Kintner-Meyer M, Balducci P, Sanquist T, Gerkensmeyer C, Schneider K, et al. The smart grid: an estimation of the energy and $\mathrm{CO} 2$ benefits. Report Prepared for the U.S. Department of Energy; January 2010.

[14] Cardell J, Dobson I, Jewell W, Kezunovic M, Overbye T, Sen P, etal. The electric power industry and climate change: issues and research possibilities. TPWRS - 00710; 2007.

[15] Enabling tomorrow's electricity system: report of the Ontario Smart Grid Forum; Jan6,2009[accessed23.09.12].

[16] Chang R, Yuan Y, Lv H, Yin W, Yang SX. Selling the smart gridpart 1: why consumers must buy in for the smart grid to succeed. Consum Electron Mag IEEE 2012;1(2):24-31. 
[17] Gungor V, Sahin D, Kocak T, Ergut S, Buccella C, Cecati C, etal. A survey on smart grid potential applications and communication requirements. IEEE Trans Ind Inf 2012; 9(1):28-42.

[18] ] Popovic- Gerber J, Oliver JA, Cordero N, Harder T, Cobos JA, Hayes $\mathrm{M}$, etal. Power electronics enabling efficient energy usage: energy savings potential and technological challenges. IEEE Trans Power Electron 2012; 27(5): 2338-53.

[19] IEEEE merging Technology portal, 2006-2012. Available at: 〈http://www.ieee. org/go/emerging tech〉 [accessed 05.06.13].

[20] Abtahi HA. Smart grid applications in the US: technical potential and regulatory barriers. Jordan J Mech Ind Eng 2010;4(1):9-14.

[21] Fan Z, Kulkarni P, Gormus S, Efthymiou C, Kalogridis G, Sooriyabandara $\mathrm{M}$, et al. Smart grid communications : overview of research challenges, solutions, and standardization activities. Commun Surv Tutor IEEE 2013; 15(1):21-38.

[22] Wang W, Xu Y, Khanna M. A survey on the communication architectures in smart grid.Comput Netw 2011; 55(15): 3604-29.

[23] Dedrick , J, Zheng Y. Smart grid adoption: a strategic institutional perspective. Annual Conference, Industry Studies Association, Pittsburgh, PA ; 2011.

[24] Estimating the costs and benefits of the smart grid: a preliminary estimate of the investment requirements and the resultant benefits of a fully functioning smart grid. Technical Report of EPRI, Palo Alto , CA, 2011.

[25] Friedman H, Sreedharan P. Wiring the smart grid for energy savings: mechanisms and policy considerations. ACEEE Summer Study Energy Eff Build 2010.

[26] 〈http:// www. Smaridnews. Com / artman / uploads/1/SG\% 20101\% 20 eBook \% 2012. 21. pdf $\rangle$ [accessed 10. 02. 14].

[27] Pica CQ, Vieira D, Dettogni G. An overview of smart grids in Brazil. In: Proceedings of the ENERGY2011: the first international conference on smart grids, green communications and it energy - aware technologies 2011 .

[28] The global smart grid federation report. Prepared by Smart Grid, Canada; 2012.

[29] Report on non-technical barriers for smart energy solutions. Report by the e-harbours expert group on Smart Energy Networks; March2013.

[30] Yu Y, Yang J, Chen B. The smart grids in China- a review. Energies 2012; 5(5): 1321-38.

[31] Woychik EC, Martinez MS. Integrated demand side management costeffec- tiveness: is valuation the major barrier to new "Smart-Grid" opportunities. ACEEE Summer Study Energy Eff Build 2012.

[32] Report by Kaushal R. Challenges of implementing smart grids in India. 14Jan 2011 [online] smart_grid_challenges.pdf [accessed02.02.14].

[33] Ramaswamy PC, Stifter M, Deconinck G. Barriers and recommendations for enabling ICT based intra-grid control applications in smart Grids. In: Proceed- ings of the IEEE conference at San Diego, CA. Published in Power and Energy society General meeting 22-26 July2012. http:// dx.doi.org / 10.1109 / PESGM. 2012. 6345081 [accessed14.10.13].

[34] Fagan J, Hindus M, Murphy M. From policy to implementation - the race to build a smart grid. Pillsbury Winthrop Shaw Pittman LLP 2009 (May7).

[35] Knight M, Brownell N. How does smart grid impact the natural monopoly paradigm of electricity supply? Grid- Interop Forum, at the conference in Chicago in December2010.

[36] ZaglagoL, Craig C, Shah H. Barriers to nationwide adoption of the smart grid technology in Ghana. In: Proceedings of the World Congress on Engineering, London UK;July3-5 2013.

[37] Yan Y, Qian Y, Sharif H, Tipper D. A survey on smart grid communication infrastructures: motivations, requirements and challenges. Commun Surv Tutor IEEE 20132013; 15(1):5-20.

[38] Eisen JB. Smart regulation and federalism for the smart grid. Harv Environ Law Rev 2013; 37:1-301.

[39] Siano P. Demand response and smart grids - a survey. Renew Sustain Energy Rev 2014;30: 461-78.

[40] VSKM Balijepalli, Khaparde SA, Gupta RP, Pradeep Y. Smart grid initiatives and power market in India. Power and Energy Society General Meeting IEEE; 25-29 July 2010. http :// dx.doi.org/ 10.1109/ PES.2010.5589947.
[41] Sood VK, Fischer D, Eklund JM, Brown T. Developing a communication infrastructure for the smart grid. In: Proceedings of the Electrical Power\& Energy Conference(EPEC)IEEE;2009.pp.1-7.

[42] Abbas A. Grid computing: a practical guide to technology and application. Firewall Media 2004

[43] Ling APA, Masao M. Grid information security functional requirement. Int J Grid Comput App 12011; 2(2):91-8

[44] Strüker J, Kerschbaum F. From a barrier to abridge: data-privacy in deregulated smart grids. In: Proceedings of the thirty third international conference on information systems, Orlando; 2012. 